\title{
AGE OF MUSKOX SKULL FOUND AT GRANDVIEW, MANITOBA
}

\author{
by Watson Crossley, R.R. No. 4, Grandview
}

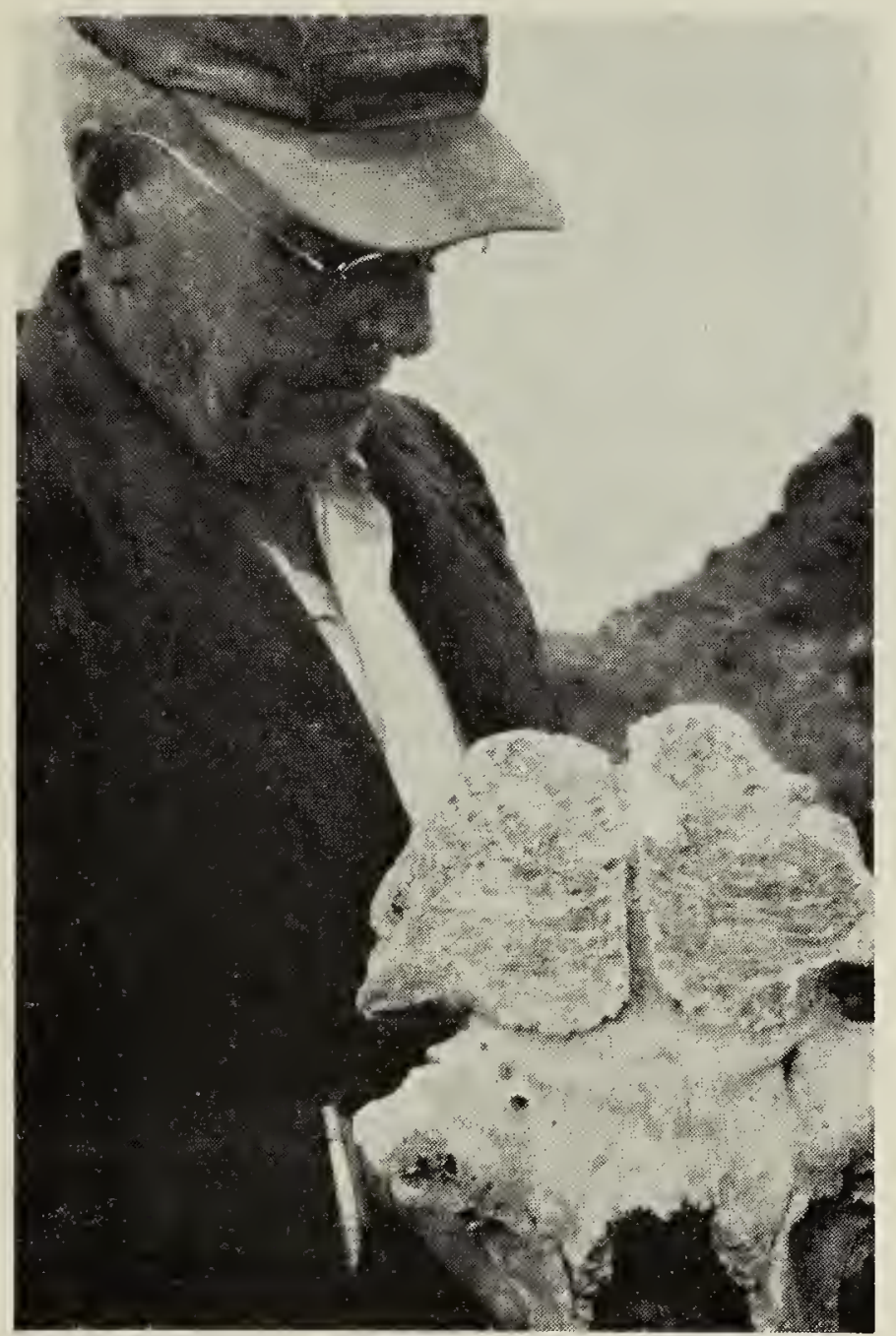

Watson Crossley and the Muskox skull

In the March, 1964 Blue Jay (22: 34) I reported the recovery of a Muskox skull from a gravel deposit along the Valley River at Grandview, Manitoba. There were indications that the gravel deposit in which the discovery was made might have been formed soon after the last glaciation period but one could only speculate as to the age of the relic. The town of Grandview is located in a valley between the Riding and the Duck Mountains on the western edge of ancient glacial Lake Agassiz.

I sent the skull to Ottawa for study by the Wildlife biologists there and it has now been returned to Grandview. The Department at Ottawa identified the specimen as being that of the modern mainland type of Muskox, Ovibos moschatus moschatus. A radiocarbon test has also been made of a sample of bone from the skull. The age of the skull is 8,600 years. The result of this age test was given to me in June, 1966 , by Dr. R. W. Klassen who called at my museum to see the skull and to inspect the site in which it had been found.

The age of this skull, determined by the first radiocarbon dating of a Pleistocene or Post-Pleistocene Muskox in Canada, is of considerable interest. It gives us some idea of when the Muskox now ranging north of Churchill were migrating through this part of Manitoba from their range, as far south as Kentucky, during the glaciated period.

\section{RIVER OTTER AT SASKATOON}

by Alan Smith, 310 Ave. X North, Saskatoon

On August 21, 1966, I was treking along the Beaver Creek Nature Trail which runs from Saskatoon south to the mouth of Beaver Creek. I followed the trail to the end of the completed portion and then continued along the edge of the South Saskatchewan River. I stopped for a moment to scan the river bank and much to my surprise I saw an adult River Otter slide down the bank and into the water.

I searched the place in the hopes of finding its den and perhaps some young. I soon found the den but there were no young, so it may have been the den of a male. His home had been left high and dry by the drop of the river as a result of the filling of the Saskatchewan River Dam Reservoir. The den had been dug about $21 / 2$ feet into the bank, and was about $1 \frac{1}{2}$ feet wide and $1 \frac{1}{2}$ feet high and was lined with strips of willow bark.

I was very proud to see such a rare and elusive mammal as the River Otter. This rewarding experience demonstrates to me how important and valuable the development of natural areas such as the Beaver Creek Nature Trail can be. 